\title{
Egy zsugorodó iparág újrapozicionálásának kérdőjelei: Magyarország cipőgyártása a rendszerváltás után
}

\author{
A declining economic sector's new positioning: \\ Hungary's footwear industry after the change of the \\ political system
}

\author{
MOLNÁR ERNŐ
}

MOLNÁR Ernő: egyetemi adjunktus, Debreceni Egyetem, Társadalomföldrajzi és Területfejlesztési Tanszék; molnar.erno@science.unideb.hu

KULCSSZAVAK: cipőgyártás, globális értékláncok, bérmunka, upgrading

ABSZTRAKT: A tanulmány - amelynek középpontjában a hazai cipőipar vizsgálata áll - három fó kérdésre keres választ. 1. Melyek azok a globális és európai trendek, amelyek az iparág működésének nemzetközi kereteit adják? 2. Hogyan élte meg a magyarországi cipőgyártás az elmúlt két évtized kihívásait a statisztikák tükrében: miként változtak alapvető teljesítménymutatói, iparon belüli súlya, területi struktúrája? 3. Hogyan élte meg a magyarországi cipőgyártás az elmúlt két évtized kihívásait a vállalatok szintjén: mi rejlik a statisztikai adatok hátterében, melyek az iparági szereplők által követett meghatározó stratégiák? Az alapvetően a rendszerváltás utáni időszakra fókuszáló kutatás szakirodalmi források mellett iparági statisztikák elemzésére, valamint kelet-magyarországi vállalati esettanulmányokra épül.

Ernő MOLNÁR: assistant professor, Department of Social Geography and Regional Development Planning, University of Debrecen; erno.molnar@unideb.hu

KEYWORDS: footwear industry, global value chains, toll-manufacturing, upgrading

ABSTRACT: The footwear industry is a highly internationalised, design and labour intensive sector which functions within the framework of so-called buyer-driven commodity chains. The costsensitive mass production shows a significant spatial mobility because of the optimisation strategies of global players: It settles in regions of cheap labour (mostly Asia and - within Europe - Southern and Eastern Europe). Companies in developed countries participate in the international division of labour as leaders of footwear value chains as well as producers of premium and special products.

The Hungarian footwear industry with its remarkable tradition had been integrated into the new global market after the change of the political system. It tried to compensate for the loss of its former foreign and domestic markets by toll manufacturing as well as by producing for special market segments. The sector experienced two major drops: The first one happened because of the overcapacity of the industry inherited from the socialist era. The second decline was caused by the unsustainability of the dominating toll-manufacturing in a changing foreign and domestic economic environment. The sector increasingly lost economic importance while its

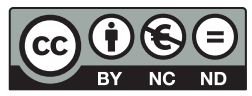


geographical centre of gravity drifted to the poorer Eastern part of the country.

The entreprises examined in this study are important players of the Hungarian footwear industry as well as of the economy of their microregions. They began with toll manufacturing, but various aspects of upgrading (increasing productivity, changing production structure, new functions within the value-adding chains) show that they are now more than classic toll manufacturers. But they are still located in peripheral microregions where labour is cheaper.

Nevertheless, these companies are forced to change their strategy because of low and decreasing profitability of toll manufacturing and because they have to diversify in present-day markets. Beside toll manufacturing, it became more important for them to develop and sell own products - first on the Hungarian market and later internationally. Present outsourcing of some of the most labour-intensive parts of production shows that it will be a big challenge to retain the whole production process of middle-priced products within Hungary (Hungarian producers are still benefiting now from their geographical position within the EU and the superior quality of their products in comparison to those of cheaper Asian and Eastern European competitors).

Alternatives may materialise in outsourcing where Hungarian companies may take the role of mediators or - in case of successful own products - the role of leaders within the value chains. Footwear industry integrating all production activities is possible to sustain only in special market segments which are less endangered by cheaper competitors.

The footwear industry is a good example of the permanent need for adaptation caused by the changing global and local economic environment influenced by economic transition as well as globalisation after the change of the political system. The strategies of the players had to be rethought again and again in order to find survival and developmental strategies. The strategies of foreign enterprises as well as the possible roles of local firms within the transnational value chains will play a decisive role in the future of this sector in Hungary.

\section{Bevezetés}

A cipőgyártás visszaszorulóban lévő iparág napjaink Magyarországán. Bár jelentősége a hazai gazdaságban a statisztikák tükrében egyre kisebb, két okból is érdekes tanulságokkal szolgál vizsgálata. Erősen nemzetköziesedett és hagyományosan nagy élőmunka-igényü iparágként azon gazdasági tevékenységek közé tartozik, melyek magyarországi fejlődésében nemigen látnak komolyabb perspektívákat a globalizálódó gazdaság korában. Joggal tehetjük fel a kérdést, hogy az iparág leépülése valóban elkerülhetetlen vagy a globalizálódó gazdaság korában is léteznek olyan szerepek, amelyekben képes lenne helyzetének újrapozicionálására, stabilizálására. Emellett különösen élesen vetődik fel a kérdés azon kistérségekben, amelyek gazdaságában ma is meghatározó szerepet játszik az iparág: megújulási kísérletének sikeressége a helyi gazdasági bázis megtartásának vagy fejlesztésének központi kérdése.

A tanulmány három fö kérdésre keres választ. 1. Melyek azok a globális és európai trendek, amelyek az iparág müködésének nemzetközi kereteit adják, továbbá - ezekből adódóan - milyen lehetőségekkel és korlátokkal szembesül a hazai cipőgyártás saját iparági pozíciói erősítésekor? 2. Hogyan élte meg a magyarországi cipőgyártás az elmúlt két évtized kihívásait a statisztikák tükrében: miként változtak alapvető teljesítménymutatói, iparon belüli súlya, valamint területi struktúrája? 3. Hogyan élte meg a magyarországi cipőgyártás az elmúlt 
két évtized kihívásait a vállalatok szintjén: mi rejlik a statisztikai adatok hátterében, melyek az iparági szereplők által követett meghatározó stratégiák?

Az első kérdést szakirodalmi tapasztalatok alapján válaszolom meg, az iparág általános fejlődési tendenciáit elsősorban a globális értékláncok elméleti keretében értelmezem (a gazdasági tevékenységek fejlődése szempontjából a külső kapcsolatrendszerek fontosságát hangsúlyozó megközelítés használatát a cipőgyártás erősen nemzetközi jellege indokolja). A második kérdés kidolgozása a KSH publikált, továbbá interneten elérhető iparági statisztikáira, míg a harmadik szerkezeti egység két jelentős méretű kelet-magyarországi cipőgyártó vállalkozás képviselőivel készített interjú anyagára épül: a hazai cipőipar dilemmáit jól reprezentáló cégeket egyrészt az iparágban, másrészt szükebb térségük gazdaságában játszott jelentős szerepük alapján választottam ki.

\section{A cipőipar globális jellemzői}

2011-ben mintegy 21 milliárd pár cipő készült a világon: a cipőtermelés 87\%-a, a fogyasztás 47\%-a kötődött Ázsiához. A legnagyobb súlya Ázsiában Kína (60\%), India (10\%), Vietnam és Indonézia (3-4\%), Ázsián kívül pedig Brazília (3-4\%), Mexikó (1,2\%) és Olaszország (1\%) cipőgyártásának volt. Az exportban Ázsia 84\%-os részesedést mutatott, amelyből Kína (és Hongkong) súlya meghaladta a 75\%-ot. A jellemzően olcsó cipőket exportáló Kína (és Hongkong) aránya ugyanakkor jóval kisebb (45\%) az exportált érték alapján, miközben a darabszámban Kína és Vietnam után következő Olaszország a világ második legnagyobb értékben (10\%) exportáló országa volt 2011-ben (APICCAPS 2012).

A számok alapján megállapítható, hogy az iparág földrajza látványosan változott az elmúlt évtizedekben. Az alacsony árfekvésű termékek gyártása a Föld különböző régióiból főként ázsiai országokba helyeződött át, ahol az iparág az egyes újonnan iparosodó országok között is számottevő súlyponteltolódásokat mutatott. Európában a helyi lábbeligyártók középkategóriás termékeinek előállítása előbb Dél-, majd Kelet-Közép-Európába települt át. A fejlett országok cipőipari körzeteiben föként a felsőkategóriás és speciális piaci szegmenseket megcélzó termékek előállítása, a termékfejlesztés és az iparág irányítása maradt (Bertram 2005; Scott 2006). A folyamat hátterében a kereskedelem liberalizációja, valamint a közlekedési és kommunikációs feltételek termelési és koordinációs költségeket csökkentő javulása áll, ami a különböző piacokra termelő cipőipari szereplők számára globális szinten optimalizált termelést tesz lehetővé. Az iparág nagy élőmunkaigénye miatt a cipőgyártás telephelyválasztását (főként az alacsonyabb árfekvésű szegmensekben) nagyban befolyásolják a munkaerőköltségek. A termelés és fogyasztás költséghatékonysági okokból bekövetkező térbeli szétválása, valamint az iparágon belüli kereskedelem - funkcionális munkamegosztás elmélyüléséből adódó - növekedésével egyre nagyobb az ex- 
port aránya az iparág forgalmában. 2010-ben a cipőipar értékesítéseinek közel kétharmada a kivitelből adódott, a részesedését az összforgalomból 2015-re - további növekedést prognosztizálva - 70\%-ra becsülik (IBISWorld Industry Report 2010; Scott 2006).

A cipőgyártás földrajzának megértéséhez a globális értékláncok elméleti koncepciója hasznos keretet kínál. A modell a gazdasági tevékenységeket az elóállítandó termék megtervezésétől, illetve nyersanyagának ki- vagy megtermelésétől, annak feldolgozásán át a késztermék értékesítéséig, továbbá a termeléshez és fogyasztáshoz kötődő szolgáltatásokig egymásra épülő értékteremtési lépésekként értelmezi (Kulke 2007; Schamp 2008). Az értékláncok különböző szereplőket integrálnak, akik eltérő mértékben járulnak hozzá az értékteremtéshez, és akiknek egymáshoz füződő kapcsolatait változó szimmetriájú hatalmi viszonyok jellemeznek (Gereffi, Humphrey, Sturgeon 2005). A cipőipar helyzetével foglalkozó munkák általában kiemelik, hogy a 20. század utolsó két évtizedében mindinkább jellemzővé váltak az iparágban az ún. fogyasztó vezérelte globális áruláncok, az erősen aszimmetrikus, a beszállítók egyoldalú függőségével leírható struktúrák elterjedése. A design- és élőmunka-igényes iparágakra jellemző koordinációs mechanizmus lényege, hogy az árulánc profitcentruma és legfontosabb ellenőrző pontja a termék marketingjének és értékesítésének fázisa: a láncolatot ezért a fogyasztókkal közvetlen kapcsolatban lévő, de termelö tevékenységet nem végzo", többnyire a fejlett országok centrumtérségeihez köthető áruházláncok és divatmanufaktúrák irányítják (Cséfalvay 2004). Az értékláncok e fajtájának iparági elterjedését nagyban segítette a cipőipari termékek kereskedelmének szervezeti koncentrációja, a márkaépítés jelentőségének növekedése, a beszállítókkal szemben növekvő elvárások (gyorsaság, rugalmasság, képesség a megrendelt termékek egyedi jellemzők szerinti minőségi legyártására) és a termelési költségek lefaragása érdekében újabb (olcsóbb) beszállítók értékláncba történő bekapcsolása (Schmitz 2006). A cipőgyártó főként olcsó munkaerejével vesz részt az értékláncban, miközben a - szakirodalomban megjelenő vélemények szerint - a rendszer működéséből származó jövedelmekből csak korlátozott mértékben részesül (általános tendencia a szükebb értelemben vett termelés értékteremtésben játszott szerepének csökkenése). Ráadásul az értéklánc irányítójának termelési költségek lefaragására irányuló törekvése állandó nyomás alatt tartja a termelőt, és fenntartja annak a lehetőségét, hogy idővel olcsóbb beszállítóval váltsák fel, azaz kiszorítsák az értékláncon belüli munkamegosztásból (Kaplinsky 2004; Schmitz 2006).

A cipőiparban tehát különösen releváns a megállapítás, miszerint nem a globális értékláncokba való bekapcsolódás ténye, hanem annak mikéntje perdöntő egy adott szereplő jövedelemszerzési esélyeiben (Kaplinsky 2004). Európában elsősorban a köztes helyzetű (nem irányító pozícióban lévő, de már nem feltétlenül olcsó telephelynek számító), nemzetközi gazdaságba erősen integrálódott, fejlettebb kelet-közép-európai országok esetében merül fel a kérdés, hogy miként növelhető a globális értékláncokban való részvételükből származó haszon, valamint hogyan stabilizálható tartósan egy térség gazdasága a globális 
értékláncok rendszerében, ha ellentmondás feszül a terület sikerességéből adódó jövedelem- vagy költségnövekedés és az egyes gazdasági tevékenységek költségérzékenysége között. A dilemma minden olyan nemzetköziesedett gazdasági tevékenység esetében megfogalmazódik, ahol a telephelyválasztásban költséghatékonysági szempontok is szerepet játszanak, de - iparági sajátosságaikból adódóan - különösen élesen vetődik fel a könnyüipari tevékenységekben (textil- és ruházati ipar, cipőgyártás). A szakirodalomban lehetséges válaszként elsősorban az ún. minőségi előrelépés, az értékláncon belüli pozíció erősítése fogalmazódik meg. A helyi hozzáadott érték ilyen növelése megmutatkozhat a termelés hatékonyságának javításában (process upgrading), nagyobb hozzáadott értéket tartalmazó termékek eloállításában (product upgrading), új funkciók megszerzésében (functional upgrading) vagy új termékek (iparágak) értékláncainak meghódításában (intersectoral upgrading) (Dicken 2011; Humphrey, Schmitz 2002). A nagyobb helyi hozzáadott érték többletjövedelmeket és a versenytársak által nehezen reprodukálható teljesítményeket jelent, ezért a hazai szakirodalomban „offenzív szerkezetváltásként” (Kiss 2010), „feljebb lépésként” (Szalavetz 2012) vagy „megújításként” (Smahó 2012) nevesített minőségi szerkezetváltás vizsgálata számos iparágra (köztük a cipőiparra is) kiterjed.

Az értékláncok belső munkamegosztásában való feljebb jutás - a különböző iparágak vizsgálatának tapasztalatai alapján - jelentős összefüggést mutat az értékláncok koordinációjának jellegével. A cipőipar általánosan jellemzőnek tartott, fogyasztó vezérelte áruláncain belül - brazíliai és portugáliai esettanulmányok szerint - a minőségi előrelépés különböző dimenziói közül leginkább a termelési folyamat és a termékszerkezet fejlődése valósul meg. Amennyiben az értéklánc irányítója hosszabb távon is rá van utalva beszállítója sikerességére (mert nehezen tudja lecserélni), úgy aktívan segítheti annak fejlődését (Schmitz 2006). Kevésbé egyértelmű a funkcionális fejlődés lehetőségének megítélése: a termelési folyamaton túli kompetenciák (termékfejlesztés, márkaépítés, marketing) fejlesztése nemcsak az értéklánc irányítójának érdekeit keresztezheti (akinek a megrendeléseitől a beszállító kapacitásainak lekötése nagyban függ), de jelentős anyagi forrásigénye miatt is korlátokba ütközhet. Ezzel együtt - részben a cipőipari értékláncok eltérő jellegéből adódóan - akadnak példák a funkcionális változásokra. Brazíliában, ahol az amerikai megrendelők - a szakirodalmi tapasztalatok szerint - nemigen bátorítják beszállítóik funkcionális fejlődését, egyes iparági szereplők egyidejüleg több értékláncban is részt vesznek: egyrészt folytatják a globális piacra irányuló, kizárólagos termelő tevékenységüket, másrészt a hazai és regionális piacon saját termékek fejlesztésével és márkaépítéssel kísérleteznek (Navas-Alemán 2011; Schmitz 2006). A termelésen kívüli funkciók erősítésének alapvetően eltérő irányát mutatják azon tajvani és olasz (korábban) cipőgyártó cégek, akik - miután termelőként már nem versenyképesek - ún. háromszögrendszerü termelés keretében, az értéklánc irányítói és a termelő tevékenységek végzői (Kína, Románia) közé közvetítőként lépnek be (Kaplinsky 2004). 


\section{A magyarországi cipőgyártás statisztikai adatok tükrében}

A magyarországi cipőipar gyáripari fejlődése az 1920-as évektől kezdődött. A 2. világháború előtti alig 2,4 millió párnyi lábbeligyártás 1960-ig mintegy 21 millió párra nőtt. A termelés 1978-ban, több mint 46 millió párral érte el maximumát, amelyet 1985-ben - bő 45 millió párral - ismét megközelített. Magyarország az 1980-as évek Európájában közepes méretủ cipőipari termelőnek számított: Kelet-Közép-Európában Lengyelország, Csehszlovákia, Románia, Jugoszlávia és az NDK is megelőzte. A nemzetközi munkamegosztásba történő bekapcsolódását sajátos kettősség jellemezte: míg a hazai lakosság ellátása és a Szovjetunióba irányuló, nyersanyagok, energiahordozók importjának ellentételezését célzó cipőgyártás saját kollekciókon alapult, addig a mind jelentősebbé váló, devizatermelést szolgáló nyugati irányú export bérmunkázást jelentett (Cseh, Farkas, Geiger, Várszegi 2002). A bérmunkát elsősorban az Észak és Dél (Nyugat és Kelet) közötti gazdasági kapcsolatok egyik jellegzetes formájának tartják, melyben a fejlett gazdaság tőkéje és technológiai háttere a kevésbé fejlett gazdaságok olcsó munkaerejével párosul. A bérmunkázás Magyarországon nem teljesen azonos a fejlődő országok többségére jellemző modellel: itt a bérmunkázás - a rendelkezésre álló iparági kultúrának és termelőeszközöknek köszönhetően - kezdetben is összetettebb tevékenységeket jelentett, amit a statisztikákban megjelenő nagyobb hozzáadottérték-arány bizonyít (Antalóczy, Sass 1998). Fontos tehát látni, hogy Magyarországon nem a globalizáció periferikus térségekben érvényesülő iparosító hatása hozta létre a cipőipart: az iparág a két világháború között kibontakozó, a hazai piac ellátását célzó importhelyettesítő iparosítás eredményeként született, és - már a rendszerváltás előtt is jellemző - kettőssége dacára nagyobbrészt saját termékeket gyártott az 1980-as évek végéig.

A piacgazdasági átmenet idején a szocialista időszakban állami nagyvállalatok által dominált iparág szervezeti háttere jelentősen átalakult. A nagyobb vállalatok (Duna Cipőgyár, Minőségi Cipőgyár, Sabaria Cipőgyár, Tisza Cipőgyár) és szövetkezetek túlnyomó többsége feldarabolódott, részben felszámolták őket, tulajdonosi szerkezetükben fontos szerephez jutott a külföldi (fóként német, olasz, osztrák, svájci) tőke. A KSH Cég-Kód-Tár 2010/4. adatbázisa 270 db társas vállalkozást regisztrált a cipőiparban: az ismert létszámú vállalkozások 63\%-a mikro-, 23\%-a kis-, 12\%-a közép- és 1\%-a - legalább 250 alkalmazottal rendelkező - nagyvállalkozás (a martfüi Lorenz Shoe Group Kft., a csengeri Szamos Kft. és a balassagyarmati Ipoly Cipőgyár Kft.) volt. A KSH tájékoztatási adatbázisa szerint 2011-ben 100 db cipőgyártó működött Magyarországon (a két forrás adatainak számottevő eltérése arra vezethető vissza, hogy utóbbi az iparág mikro- és kisvállalkozásait csak részben tartalmazza).

A hazai cipőipar zsugorodása a rendszerváltás előtt és az átalakulás idején is jelentős volt (vö. 1. táblázat): 1989-ben 30 millió, 1990-ben 25 millió, 1993-ban pedig már csak 12 millió pár körül alakult a gyártott cipők mennyisége. Az 1990-es évek folyamán és az ezredfordulót követő években kismértékű ingadozásokkal ez a nagyságrend volt jellemző, majd - egy nagyobb hullámvölgy után - 
2011-ben a gyártott cipők mennyisége ismét meghaladta a 10 millió párat. Különösen az alkalmazottak számának alakulása ad szemléletes képet a lábbeligyártás leépülésének 1989 utáni két nagy hullámáról. 1989-1995 között az 1989. évi létszám (közel 32 ezer fö) több mint 40\%-át, 2000-2005 között az ezredfordulóra jellemző létszám (20 ezer fö) több mint 55\%-át veszítette el az ágazat (az iparágban alkalmazottak száma már a rendszerváltás előtt is csökkenőben volt, de a rendszerváltással ez a folyamat látványosan felgyorsult). 2005 után is zsugorodott a cipőipar és a gazdasági recesszió sem hagyta az ágazatot érintetlenül, de az elmúlt években már nem volt földcsuszamlásszerű visszaesés az iparág foglalkoztatásában: a 2009-ben regisztrált mintegy 6000 fös létszám 2012-re ráadásul (közel 7000 főre) növekedett. Fontos látni, hogy a cipőgyártás foglalkoztatásának leépülése a rendszerváltás után nem volt nagyobb az ipari átlagnál (sőt, az ágazat egészéhez hasonlóan a lábbeligyártás is növelte foglalkoztatottjainak számát az 1990-es évek második felében), de az ezredforduló utáni talajvesztés egyértelmű pozícióromlást eredményezett. A cipőgyártásnak az ipar egészétől eltérő fejlődési pályáját a termelési és exportértékesítési adatok jól szemléltetik: a vizsgált iparág az időszak egészében az ipari átlagtól elmaradó dinamikát mutat (2005 után részben az alacsony bázis, részben a recesszió több kulcsiparágat erősen érintő hatása miatt jobbak a mutatói). A rendszerváltás idején mutatott teljesítményét - az infláció mértékével korrigált adatok alapján - napjainkig csak az export terén tudta meghaladni. Az iparág súlya - összhangban a hazai újraiparosodás ágazati szerkezetével (Barta, Czirfusz, Kukely 2008) - előbb jelentős mértékben csökkent (1985ben az ipar 1,3-2,5\%-át képviselte a legtöbb mutató esetében, 2005-re viszont 0,2\% alá, a foglalkoztatás esetében 1,2\% alá esett az érték), majd 2005 után mérsékelt pozícióerősödése figyelhető meg.

A lábbeligyártás leépülési hullámai közül az első - a piacgazdasági átalakulásból fakadó nehézségek mellett - a külső és belső piacok beszűkülésével

1. táblázat: A lábbeligyártás néhány teljesítménymutatójának alakulása az ipar egészével összevetve a rendszerváltás után (az 1989. évi érték \%-ában)

Dynamics of some indicators of the footwear industry after the change of regime, in comparison to the whole manufacturing industry (in percentage of the 1989 value)

\begin{tabular}{lccccrr}
\hline \multicolumn{1}{c}{ Mutató } & 1990 & 1995 & 2000 & 2005 & 2010 & 2012 \\
\hline Termelési érték & 88 & 52 & 64 & 25 & 27 & 47 \\
Exportárbevétel* & 88 & 56 & 79 & 61 & 96 & 125 \\
Alkalmazottak & 88 & 57 & 63 & 27 & 21 & 22 \\
\hline \multicolumn{7}{c}{ Az ipar egésze } \\
\hline Termelési érték & 92 & 68 & 117 & 151 & 155 & 161 \\
Exportás & 82 & 261 & 419 & 535 & 572 \\
Alkalmazbevétel & 91 & 56 & 62 & 56 & 50 & 50 \\
\hline
\end{tabular}

* A lábbeligyártás exportdinamikája - részletesebb adatok hiján - a bőrtermék- és lábbeligyártásra számítva. Adatok forrása: KSH. 
magyarázható: a Szovjetunió összeomlásával legfontosabb piacát veszítette el az iparág. Az elmélyülő transzformációs válság a hazai vásárlóerőt csökkentette, míg a külkereskedelem liberalizációja a külső - föként távol-keleti - versenytársak hazai piacon történő megjelenését segítette: az 1980-as évek végén még 60-70\%-os, az ezredfordulón már csak 10\% alatti részesedéssel rendelkeztek a hazai termelők a magyar piacon (Laki 2005). A helyzet az elmúlt évtizedben sem lett kedvezőbb: a Bőr- és Cipőipari Egyesülés adatai szerint ma Magyarországon 35-38 millió pár cipő fogy évente, amelyből mindössze 2 millió pár a hazai és 5-6 millió pár az európai termelők részesedése. Bár e két szegmens az eladott cipők 20-25\%-át jelenti, az értékesített modellek magasabb árfekvésének köszönhetően az európai áruk értékaránya 70\%-ot képviselt (Csingár 2013). Negatív hatást gyakorolt az élőmunka-igényes iparág helyzetére az élőmunka terheinek 1980-as évek végén végrehajtott jelentős növelése is (Cseh, Farkas, Geiger, Várszegi 2002).

A piaci problémák szerkezeti átalakulást eredményeztek az iparágban: a termelők többsége - nem látva esélyét egy önálló nyugat-európai megjelenés sikerének, folytatva a nyugati relációban érvényesülő rendszerváltás előtti hagyományokat - lemondott a saját termékfejlesztésről és értékesítésről, s kapacitásainak fenntartása érdekében a biztos piacot, de csekélyebb jövedelmet jelentő bérmunka irányába fordult (a folyamatot erősítette a nyugat-európai iparági szereplők fokozott érdeklődése az olcsóbb termelést lehetővé tevő telephelyek iránt). A cégek kisebbik része a versenykerülés stratégiáját választotta, azaz saját termékeit gyártva a hazai cipőpiac külföldi konkurensek által kevésbé támadott szegmenseibe (például munkavédelmi lábbelik, sportcipők, kényelmi cipők gyártása) húzódott (Laki 2005). Az ezredforduló utáni (második) leépülési hullám fó kiváltó oka a bérmunkázás lehetőségeinek mérséklődése volt: a hazai piacok elvesztése nyomán az exportértékesítés növelésében kiutat kereső, továbbra is erősen élőmunka-igényes iparág szereplőire a forint erősödése (és későbbi árfolyam-ingadozásai), valamint a minimálbérek nagyarányú emelése, a munkaerőköltségek növekedése mért csapást. A megváltozott feltételek közepette a bérmunka piaca szűkült, jövedelmezősége erősen romlott, ami egyrészt az export terén a minőségi, nagyobb hozzáadott értéket produkáló, kisebb szériás bérmunka felé tolódást, másrészt kezdetben a belföldi piacon (a minőségi import kiváltásának igényével) saját termékek fejlesztésének stratégiáját értékelte fel. Mivel sok esetben kevés volt az idő és a tőke az átállásra vagy a külföldi tulajdonos kivonta a tőkét magyarországi érdekeltségéből, 2001-2003 között tömegesen történtek vállalatbezárások (Laki 2005).

A lábbeligyártás jellegzetes élőmunka-igényes iparág: az egy foglalkoztatottra jutó termelési érték mindinkább elmaradt az ipar egészétől, az ezredfordulót követő években ötödét sem érte el az ipar mutatójának. Figyelemre méltó ugyanakkor, hogy az elmúlt években jelentősen javult a termelékenység az ipari átlaghoz képest, amiben talán a lábbeligyártás bérmunka-konstrukción kívüli teljesítményének növekedése játszott számottevő szerepet. A keleti piacok 
összeomlása ellenére, a beszükülő hazai lehetőségekkel és a külföldi megrendelők számára folytatott bérmunkázás elterjedésével nagymértékben emelkedett az exportértékesítés részaránya, amely az ipari átlagot mindvégig meghaladta a rendszerváltás után. Magyarországon az iparág jellemzője a szellemi alkalmazottak viszonylag alacsony és - az ipar egészével szemben - csökkenő aránya. A rendszerváltás után a cipőipari bruttó átlagkeresetek egyre inkább elmaradtak az ipari átlagtól: az ezredforduló utáni évtizedben alig haladták meg az ipari átlag 50\%-át (2. táblázat). Az alacsony érték fontos oka, hogy az élőmunka-igényes iparág versenyképességében meghatározó szerepet játszanak a foglalkoztatás költségei, ami erősen korlátozza a cipőipar vállalkozásainak mozgásterét az átlagkeresetek emelésében (Molnár 2013).

A cipőipar - munkaerő-igényessége folytán - fontos szerepet játszott a szocialista időszakban az elmaradott vidéki területek iparosításában, a mezögazdaságból felszabadult munkaerő foglalkoztatásában. (Így hasonló az iparág szerepe Magyarország elmaradott területeinek és a globális gazdaság perifériáinak iparosításában: az alapvetően eltérő gazdasági környezet ellenére mindkét esetben a rendelkezésre álló olcsó munkaerő a legfontosabb telepítő tényező.) Nemcsak a cipőgyárak kitelepülése, de az egyes munkák termelőszövetkezeti melléküzemágakba történő kiszervezése is számottevő volt. Az 1980as évek derekán Budapest még az iparág egyik legjelentősebb központjának számított, és a cipőipar az ország különböző területein mintegy 90 településen legalább 20 föt, 20 településen minimum 500 főt foglalkoztatott. Legnagyobb vidéki telephelyei Martfü, Kiskunfélegyháza, Nyíregyháza, Nyírbátor és Rakamaz, továbbá Szombathely, Körmend, Bonyhád és Szigetvár voltak (1. ábra). A legnagyobb kapacitású martfüi Tisza Cipőgyárban fénykorában 5400 fö dolgozott és évente mintegy 10 millió pár cipő készült.

A cipőipar kilencvenes évek végi felfutásának idején a foglalkoztatás közel 120 településen érte el a 20 föt, 10-12 település esetében pedig 500 fó felett alakult (a látszólagos növekedés azzal magyarázható, hogy az 1980-as években a termelőszövetkezetek ipari melléküzemágaiban végzett cipőipari tevékenységek nem jelentek meg az általam felhasznált akkori adatokban, de e szervezetek egy része folytatta pályafutását a rendszerváltás után is, így az 1990-es évek

2. táblázat: A lábbeligyártás néhány strukturális jellemzője a rendszerváltás után Some structural features of the footwear industry after the change of regime

\begin{tabular}{lrrrrrr}
\hline \multicolumn{1}{c}{ Mutató } & 1990 & 1995 & 2000 & 2005 & 2010 & 2012 \\
\hline A termelés egy alkalmazottra jutó értéke (az ipar \%-ában) & 42 & 26 & 20 & 14 & 15 & 25 \\
Az exportértékesítés aránya (\%) & 41 & 56 & 68 & 68 & 81 & 86 \\
Szellemi foglalkoztatottak (\%) & 16 & 11 & 9 & 11 & 9 & 9 \\
Havi bruttó átlagkereset (az ipar \%-ában) & 70 & 58 & 57 & 52 & 52 & 53 \\
\hline
\end{tabular}

*1990-ben - részletesebb adatok hiján - a bőrtermék- és lábbeligyártásra számítva. Adatok forrása: $\mathrm{KSH}$. 
1. ábra: A cipőipari foglalkoztatás Magyarországon az 1980-as évek derekán Employment in the Hungarian footwear industry in the mid-1980s

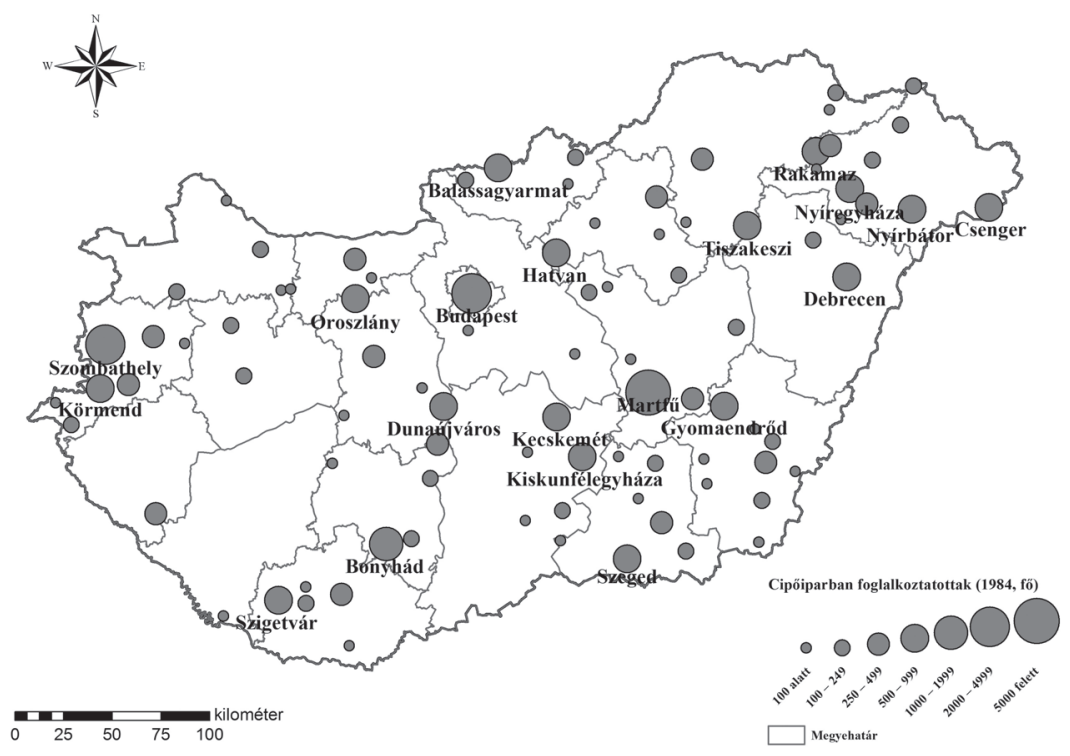

Adatok forrása: Magyarország Nemzeti Atlasza 1989, 395.

vállalkozási statisztikáiban már szerepelt). Budapest pozíciója erősen romlott, de az iparág vezető szereplői - települési szinten - alig változtak (2. ábra). Az ezredforduló utáni leépülési hullám során az iparág kritikus tömeget elérő képviselői néhány szükebb térségbe szorultak vissza (a 20 főnél többet foglalkoztató cipőipari telephelyek száma 50 alá csökkent, míg az 500 fó felettiek száma mindössze 2 db-ra mérséklődött).

- Az Alföld középső-déli részének meghatározó központja Martfü, ahol az egykori Tisza Cipőgyár telephelyén működő iparági szereplők még napjainkban is közel 1000 föt foglalkoztatnak. Számottevő súlya van a régióban Kiskunfélegyházának, Kiskunmajsának, Mezőtúrnak és Gyomaendrődnek is.

- Az Alföld északkeleti részén tömörülő cipőgyártó telephelyek közül a mintegy 700 főt foglalkoztató Csenger, továbbá Nyíregyháza, Rakamaz, Ramocsaháza, Tiszakeszi és Hajdúböszörmény jelentősebb.

- A Dél-Dunántúl területén Pécs, Bonyhád, Nagymányok és Szigetvár emelhetö ki.

- A nyugat-magyarországi térség jelentőségében erősen zsugorodott cipőiparának nagyobb központjai Szombathely és Kám.

E négy térség mellett elsősorban Balassagyarmat cipőgyártása említhető (3. ábra). A domináns (térben és időben egyenetlen) zsugorodási tendenciák mellett akadnak olyan telephelyek is, ahol a cipőipar stabil vagy növekvő fog- 
2. ábra: A cipőipari foglalkoztatás Magyarországon az 1990-es évek végén

Employment in the Hungarian footwear industry at the end of the 1990s

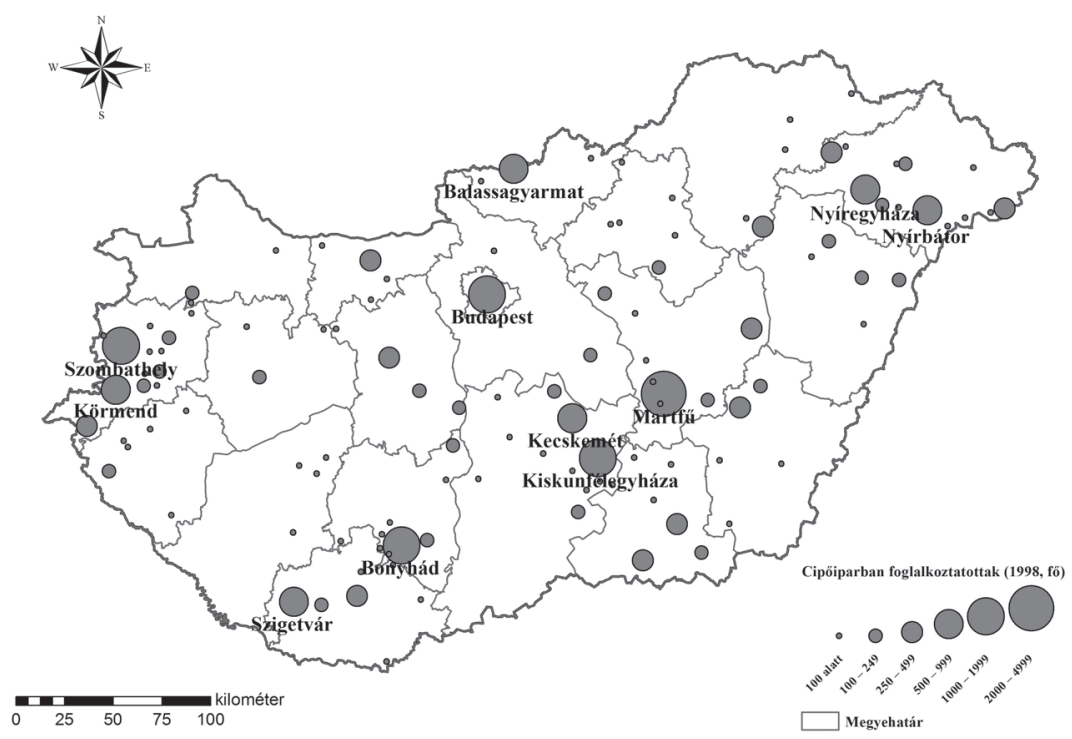

Adatok forrása: KSH Cég-Kód-Tár 1998/1. telephelyekkel korrigált adatai.

3. ábra: A cipőipari foglalkoztatás Magyarországon a 2000-es évek végén

Employment in the Hungarian footwear industry at the end of the $2000 \mathrm{~s}$

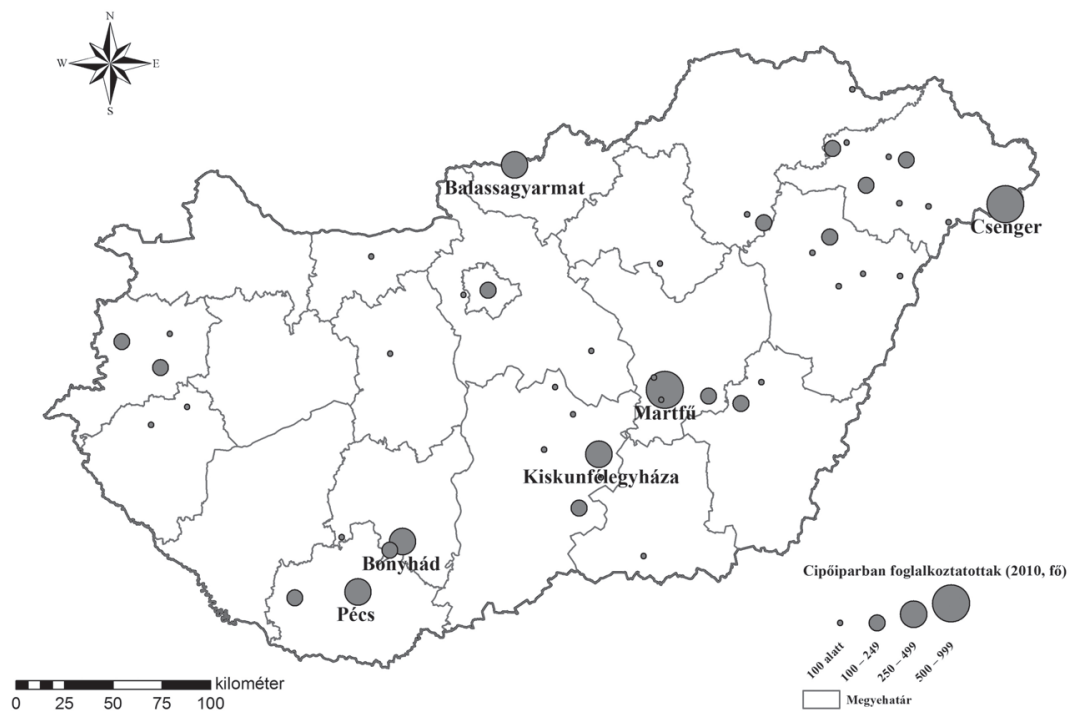

Adatok forrása: KSH Cég-Kód-Tár 2010/4. telephelyekkel korrigált adatai. 
lalkoztatást tudott felmutatni (bár az ezredforduló után ilyen település legfeljebb Kelet-Magyarországon található).

\section{A magyarországi cipőgyártás esettanulmányok tükrében}

Az esettanulmányok kelet-magyarországi vállalkozásainak (C-1 és C-2) múltja az 1970-es évek dekoncentrált ipartelepítésének időszakáig vezethető vissza. A budapesti székhelyü Minőségi Cipőgyár által létrehozott vidéki üzemegységek célja - az alföldi ipari üzemekre akkoriban jellemző módon - a mezőgazdaságból felszabaduló jelentős létszámú munkaerő helyben történő foglalkoztatása volt. A rendszerváltás gazdasági átalakulása - a keleti piacok összeomlása - a Minőségi Cipőgyárat is maga alá temette. Üzemei más hazai és külföldi cégek privatizációs kísérletei után helyi alapítású, hazai tulajdonú cipőgyártó vállalkozások (esettanulmányunk szereplői) kezébe kerültek.

Egyik vállalkozás sem nagyvállalatként kezdte működését: egyikük 1990ben 46 föt, másikuk 1993-ban 15 föt alkalmazott (utóbbi foglalkoztatottjainak létszáma az ezredfordulóra növekedett 50-60 före). A két cipőipari vállalkozás eltérő stratégiával kezdte pályafutását. Az első cég (C-1) kezdetektől fogva bérmunkára alapozta tevékenységét, s több külföldi - angol, olasz, német - partnernek végzett munka után 1991-ben vált a nyugat-európai viszonyokhoz képest olcsó cipőgyártót kereső német Josef Seibel partnerévé. A második cég (C-2) kezdetben saját fejlesztésű női divatcipőket gyártott a hazai piacra (versenykerülő stratégia), de az erősödő távol-keleti konkurencia megrendítette a termékeit árusító butikok helyzetét, így foglalkoztatása fenntartása érdekében az ezredforduló után bérmunkára váltott: a német Lugina partnere lett. A cégek bérmunkázóvá válásával piaci kapcsolataik földrajzi dimenziói is kitágultak. Az első cég (C-1) közepes árfekvésű, vegyes összetételü lábbelijeinek egyharmada az Amerikai Egyesült Államokba, kétharmada a világ 30-40 országába (például a Közel-Keletre, Hongkongba és Ausztráliába) kerül. A második cég (C-2) női kényelmi cipőit is az USA-tól Ázsiáig értékesítik.

A bérmunkáztató növekvő volumenű megrendelései mindkét cég fejlődésében óriási szerepet játszottak. Az első cég (C-1) 1992-ben mintegy 200 ezer pár cipőt gyártott, ez a szám az ezredforduló után évi 1 millió párra növekedett, majd az utóbbi években jelentős mértékben csökkent: a gyártott cipők mennyisége tavaly 600 ezer pár körül alakult. A másik vállalkozás (C-2) 30-40 ezer pár cipőt készített kezdetben, amely napjainkra - testvércégének teljesítményét is figyelembe véve - 550-600 ezer párra bővült. Mindkét iparági szereplő fontos szerepet játszik bérmunkáztatója ellátásában: a Josef Seibel az elmúlt években 3-3,5 millió pár cipőt értékesített globálisan, amelynek 18-26\%-a (csökkenő arányban) magyarországi partnerénél készül, míg tanulmányunk másik szereplője - legnagyobb beszállítóként - mintegy 30\%-át adja a Lugina cipőinek. A né- 
met vállalatok növekvő megrendelései a két oldal függőségének kölcsönösségét erősítették. A kapacitások fejlesztésére mindkét cég jelentős, részben európai uniós pályázatokon elnyert összegeket költött. Az épületek felújítása és bővítése mellett a gépállomány korszerüsítése nemcsak a kapacitások növelésének, hanem a termelési folyamat hatékonyságjavításának (gyorsaság, minőség) is kulcseleme: az amortizálódott gépállomány cseréje mellett főként a kézi munka kiváltását és az új termékek előállításának képességét célozza. Mindkét cég jó példa arra, hogy a bérmunkáztató - érdekelt lévén a termelés hatékonyságának növelésében - anyagilag is közremüködik a géppark fejlesztésében. Az interjúkból megállapítható, hogy a hatékonyság folyamatos javítása az új gépek beszerzése mellett a minőségbiztosításon, valamint a kiadások racionalizálásán alapul. A vállalkozások foglalkoztatása jelentős mértékben nőtt: az első cég (C-1) mintegy 500 főt, míg a második vállalkozás (C-2) - testvércégével - mintegy 320 főt foglalkoztat napjainkban.

A cipőgyártó vállalatok működését alapvetően a bérmunkázás keretfeltételei határozzák meg. Megrendeléseik elnyerése szezonról szezonra egyfajta kváziverseny keretében történik: a bérmunkáztató a felmutatott ár-érték arány alapján mérlegel, elvárásai között a minőség és a szállítások pontossága szerepel első helyen, de a rugalmasság, a gyors alkalmazkodás képessége sem lebecsülendő. Másrészt viszont sokat számít a bizalom, a már kialakult egy-két évtizedes kapcsolati tőke, ami nehezíti a bérmunkázó gyakori cserélgetését. $\mathrm{E}$ két szempont eltérő arányú érvényesülése lehet az oka annak, hogy miközben második szereplőnk - saját bevallása szerint - ma már nemigen küzd a megrendelésekért, addig az első cég a kapcsolati tőke fontossága ellenére is azt tapasztalja, hogy évről évre megmérettetik bérmunkáztatója többi beszállítójával (Európában bolgár és cseh cégekkel). A megrendelőnek a termelés koordinációjában játszott irányító szerepéhez nem férhet kétség. Az első cég (C-1) esetében például a termékeket értékesítő bérmunkáztató a szezon elején elküldi a gyártási tervet, majd heti rendszerességgel a termékek részletes leírását, a technológiai utasításokat és a határidőket tartalmazó megrendeléseket. A bérmunkáztató biztosítja mindkét cég esetében a főbb alapanyagokat. Mind a Josef Seibel, mind a Lugina kihelyezett német technikusokat foglalkoztat partnereinél a termelés ellenőrzésére (4. ábra). E jellemzők a design- és munkaigényes termékek előállítására szerveződő, fogyasztó vezérelte globális áruláncok sajátosságait mutatják, ahol az erős külső ellenőrzés alatt álló gyártó elsősorban olcsó munkaerejével járul hozzá az értéklánc egészének sikeréhez.

A cipőgyártó vállalkozások komoly termelési kompetenciáit mutatja ugyanakkor, hogy - bár első megrendeléseik még csupán cipőfelsőrész-készítést jelentettek - napjainkban mindketten a cipőgyártás teljes technológiai sorával (szabászat, tűzöde, talpelőkészíto, aljaüzem, csomagolás, minőség-ellenőrzés) foglalkoznak. Székhelyükön kívüli telephelyeik is vannak: az első cég (C-1) Bátorligeten 40-50 főt, a második vállalkozás (C-2) Mezőcsáton 60-65 főt foglalkoztat, a legmunkaigényesebb tűzödei tevékenység (cipőfelsőrész-készítés) egy 
részének kihelyezésével. Emellett mindkét cég maga is bérmunkáztat, bár a jellemzően tűzödei tevékenységek kiszervezésében jelentős aránybeli különbségek vannak. Az első cég (C-1) a romániai Margittán és a kárpátaljai Péterfalván rendelkezik bedolgozókkal (ezek összesen 100 embert foglalkoztatnak). A második vállalkozás (C-2) beszállítói hálózata kiterjedtebb: Abaújszántó, Csenger, Dunapataj, Nyírbogát, Nyírmeggyes, Mezőcsát, Mezőtúr, Orgovány, Rakamaz, Salgótarján, valamint Nagyvárad (3 cég) településein általában további 700-800 főnek adnak munkát. A beszállítók a rugalmas kapacitáshasznosítás eszközei, továbbá alkalmazásukkal - a legmunkaigényesebb tűzödei tevékenység kiszervezésével - (különösen határon túli partnerek bevonásával) komoly költségcsökkentés érhető el. E karcsúsítási törekvésekkel áll szemben a munka nagy távolságra történő kiszervezésének logisztikai többletköltsége, továbbá a helyi foglalkoztatás fenntartásának szempontja. Miután az ellenérvek is nagy súllyal esnek latba, a tűzödei munka egészének határon túli kiszervezése helyett mindkét cég fenntartja saját tűzödei kapacitásait, valamint részben belföldön adja ki a munkát. A munkaerő költségére leginkább érzékeny értékteremtési lépés bérmunkába történő kiadása ugyanakkor akár első lépésként is értelmezhető egy hosszabb távon megcélzandó szerepváltás, a bérmunkáztató értékláncán belüli, tényleges termelést egyre kevésbé végző, kelet-ázsiai vagy olaszországi példákból ismert közvetítői pozíció felé (4. ábra).

A megrendelő elkötelezettségének erősítése érdekében mindkét cipőgyártó törekszik az értékláncon belül elfoglalt pozíció javítására. A tömegtermelésen túl mintacipőket is gyártanak vásárlójuk számára, ráadásul ebben ők a megrendelőik legfontosabb beszállítói. Mindkét vállalkozás a közép-európai logisztikai funkció megerősítésében látja helyzete további javításának lehetőségét. Az első cég (C-1) már müködő logisztikai központja nemcsak a helyben, hanem a Bulgáriában gyártott Josef Seibel cipők egy részének raktározását is végzi: e szerepkör nemcsak 20 fó foglalkoztatását jelenti, hanem javítja is a vállalat alkupozícióját a bérmunkáztató megrendeléseiért folytatott versenyben (a 4. ábra arra is utal, hogy a késztermékek kiszállítása nemcsak a németországi központba, de - kikötőkön keresztül - közvetlenül a tengerentúlra is irányulhat). A második vállalkozásnál (C-2) folyamatban van egy logisztikai központ saját telephelyen történő kialakítása, ami nemcsak önmaga, hanem a környéken (Nyíregyháza, Rakamaz, Martfü) működő cipőipari cégek, továbbá a horvát és román partnerek kiszolgálását is célozná. Mindkét cipőgyártó igyekszik a bérmunkáztató partner közvetlen tőkebefektetéseit növelni, amivel a magyarországi érdekeltségekhez való kötődés tovább erősödhetne. A Josef Seibel leányvállalatot alapított beszállítója (C-1) telephelyén, felvásárolta a partnere számára cipőtalpakat gyártó, helyben müködő talpgyártó céget és gépberuházásokkal javította partnere hatékonyságát. A második vállalkozás (C-2) gépállományának fejlesztésében is jelentős a német partner szerepe, aki új gyártócsarnok felépítését is finanszírozta a telephelyen. Az esettanulmányok vállalatai tehát a klasszikus bérmunkán túlmutató szerepben ágyazódnak be az 
4. ábra: A vizsgált magyarországi cipőgyártó vállalkozások helyzete transznacionális értékláncaik rendszerében

Position of the examined Hungarian shoe producers within their transnational value chains

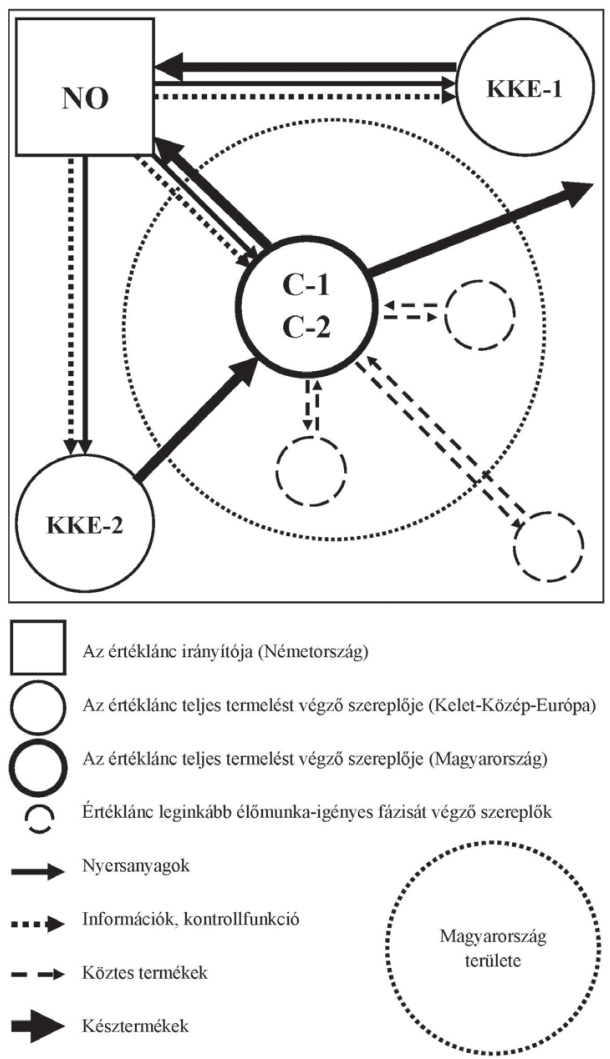

iparág nemzetközi munkamegosztásába, hiszen a szűkebb termelésen túl egyéb funkciókat is megszereztek a német partnereik által irányított értékláncokban. Értékláncukon belüli hasonló, köztes helyzetüket jól jellemzi „bérmunkáztató bérmunkázó" pozíciójuk (4. ábra).

A bérmunka a jelentős termelőkapacitásokkal rendelkező, de tőkeszegény vállalkozások jellemző túlélési stratégiájává vált a rendszerváltás utáni Magyarország könnyűiparában. Előnye, hogy csökkenti a gyártó termelési költségeit, mentesíti azt a piacszerzés gondjaitól, miközben elősegíti a műszaki színvonal és a foglalkoztatás javítását. De minden pozitívuma ellenére kényszerpálya: kevéssé jövedelmező, hiszen a bérmunkázó a munkaerejét adja egy olyan iparágban, ahol a termelési költségek lefaragásában a munkaerőköltségeknek meghatározó szerepük van (az értéklánc legjövedelmezőbb szegmensei nem a bérmunkázóhoz köthetőek), másrészt a készen kapott feladatok - az érintettek véleménye szerint - „szakmai elbutulást” okoznak. Részben e szak- 
mai-jövedelmezőségi szempontok, részben viszont a több lábra állás, a bérmunkáztatótól való függetlenedés igénye motiválja mindkét általam vizsgált iparági szereplöt arra, hogy saját termékekkel is megjelenjen a piacon.

Az első cég (C-1) 2007-ben kezdte el saját márkanév alatt futó gyermekcipőgyártását, amely 2012-ben már 60-70 ezer pár lábbeli gyártását jelentette és a cég cipőgyártáshoz kötődő árbevételének közel 20\%-át adta. A gyermekcipőkben elsősorban azért látott perspektívát a vállalat vezetése, mert azok elóállítása az átlagosnál több kézi munkát és nagyobb pontosságot igényel, így kevésbé kedvelt a cipőgyártó cégek körében (versenykerülés stratégiája). Igazán olcsó e kategóriában sem tud lenni a vállalat, ezért termékeinek minőségi kivitelezésére fókuszál, valamint speciális piaci szegmensek felé mozdul el: a hagyományos cipők mellett tanúsítvánnyal rendelkező egészségügyi korrekciós, továbbá megelőzési célokat szolgáló, döntött sarkú (ún. supinált) cipőket gyárt. A belül vastagabb talpú, nem ortopéd külsejű cipők napjainkban gyermekcipőik több mint felét adják. Saját termékeiket többnyire hazai cipőkereskedőknél helyezik el, de a vállalkozás kísérletezett piaci megjelenéssel Ukrajnában, Oroszországban és - a Josef Seibel hathatós támogatásával - Németországban is. A másik vállalkozás (C-2) felsőkategóriás női divatcipő kisszériás gyártásának előkészítésén dolgozik (a saját kollekció piaci bevezetésére várhatóan még 2013-ban sor kerül). A választás oka ebben az esetben is elsősorban a kisebbnek vélt konkurencia, de hangsúlyozandó, hogy a cég a bérmunkázás előtt is női divatcipők fejlesztésével foglalkozott. A magyar piacon próbálnak elindulni, majd az európai és a világpiacra történő kilépés a cél. Közös a két cég saját termékeinek pozicionálásában, hogy egyikük sem keresztezi partnere piaci érdekeit.

A cipőipari értékláncokon belüli pozícióerősítés egyik kulcskérdése a humánerőforrás-háttér. Az iparág nemzetgazdasági átlagtól jócskán elmaradó átlagkeresetei általában nem túl vonzóak a munkavállalók számára, de a vizsgált vállalkozások térségeiben - ahol nemigen akadnak helyi foglalkoztatási alternatívák - nem számítanak rossz lehetőségnek. (A Nemzeti Foglalkoztatási Szolgálat 2010. évi adatai alapján az első vállalkozás kistérségében $57,3 \%$-os volt az aktivitási és $24,1 \%$-os a munkanélküliségi ráta, a második cég kistérségében $51,4 \%$-os volt az aktivitási és $24,4 \%$-os a munkanélküliségi ráta a 15-64 éves korosztály körében.) Nem meglepő tehát, hogy egyik szereplőnek sincs különösebb problémája a munkaerő-utánpótlással, amiben szerepet játszik az is, hogy az alkalmazottak jelentős része betanított munkás, akikkel szemben csekély előképzettségi igényeket támasztanak. Másrészt viszont tevékenységük növekvő képzettségi igényei, valamint a munkavállalói gárda fiatalításának szüksége miatt mindkét cég hangsúlyt helyez a szakmunkás-utánpótlás biztosítására. Az első cégnél (C-1) a helyi középiskolában folyó cipőipari szakmunkásképzés és a munkaügyi központ által szervezett képzések említhetőek meg, míg a második vállalkozás (C-2) mezőcsáti telephelyén tervezi a munkaügyi központtal közös, OKJ-s képzést biztosító felnőttképző központ kialakítását (Mezőcsáton nem is működött, a közeli Tiszaújvárosban pedig megszűnt a korábban létező cipőipari szakmunkásképzés). 
A két cég termelésének felfutását - a zsugorodó hazai iparági környezetben - nemigen követte a kapcsolódó háttéripar fejlődése. Inputbeszerző tevékenységük csekély mértékben kötődik Magyarországhoz, ami az alapanyag-beszerzés egy részét végző bérmunkáztató preferenciáival, valamint a cipőiparhoz kötődő hazai iparágak (bőripar, könnyüipari gépgyártás) rendszerváltás utáni leépülésével magyarázható. A bérmunka önállóan beszerzett kellékanyagai (C-2) és a saját termékek bőralapanyagai (C-1) általában külföldről érkeznek. A beszerzések földrajzi hatóköre gyakorlatilag globálisnak tekinthető: az első vállalkozás Argentínából, Indiából, Olaszországból és Oroszországból érkező minőségi bőröket, valamint Lengyelországból, Olaszországból és Törökországból származó talpakat is használ. A két cég termelöeszközei - az iparágra jellemző módon - többnyire német és olasz gyártmányúak. A cégek szűkös hazai inputjaira is az első vállalkozás (C-1) kínál szemléletes példát: kiemelendőek a Martfün vásárolt szabászkések, a Püspökladányban beszerzett ragasztók, a Nyíregyházán vásárolt cérna és a csomagolásnál használt dobozok, egyes Szombathelyről származó gyártóeszközök, valamint a Budapestről rendelt gépjavító szolgáltatások.

\section{Összegzés}

A cipőipar erősen nemzetköziesedett, többnyire fogyasztó vezérelte áruláncok keretében szerveződő, design- és élőmunka-igényes iparág, ahol az alacsony és középkategóriás termékek erős területi mobilitást, jelentős földrajzi súlyponteltolódásokat mutató, költségérzékeny tömegtermelése - a globális optimalizáció jegyében - olcsó munkaerejü térségekbe (főként ázsiai országokba, Európán belül Dél- és Kelet-Európába) települ. A fejlett országok iparági szereplői a cipőipari értékláncok irányítóiként, továbbá felsőbb kategóriás és speciális kisszériás termékek gyártóiként vesznek részt a területi munkamegosztásban.

Magyarország nagy hagyományokkal bíró cipőipara - az 1980-as évek előzményei után - ebbe a környezetbe csöppent bele a rendszerváltás idején: nagyarányú külső és belső piacvesztését bérmunkázóvá válással, valamint a hazai piac speciális szegmenseire fókuszáló saját gyártással igyekezett átvészelni. Két jelentős leépülési hulláma közül az első a szocialista időszakból örökölt kapacitások egy részének megváltozott körülmények közti túlméretezettségéből, a második a dominánssá vált bérmunkázó stratégia korábbi formájának fenntarthatatlanságából adódott. Az iparág mind súlytalanabb szereplővé vált az iparon belül, miközben területi súlypontja egyre inkább áthelyeződött a jelentős iparági hagyományokkal rendelkező, de periferikus helyzetű alföldi területekre.

A hazai cipőiparban és szükebb térségeik gazdaságában egyaránt jelentős szereplőnek számító, két esettanulmányban vizsgált vállalkozás is bérmunkázóként nőtt nagyra, de a minőségi előrelépés különböző dimenziói (a termelés 
hatékonyságának növelése, termékszerkezet-váltás, új funkciók az értékláncon belül) jól megfigyelhetőek fejlődési pályájukban, s ennek nyomán megrendelöjükhöz füződő kapcsolatuk egyre inkább túlmutat a klasszikus bérmunkán. Bár periferikus helyzetű térségekben működnek, ahol az olcsó munkaerőre épülő tevékenységek mozgástere nagyobb, a bérmunka csekély és szűkülő jövedelmezősége, továbbá a több lábra állás igénye őket is stratégiaváltásra ösztönzi. A bérmunka mellett - a szakirodalomban leírtakhoz hasonlóan - a saját termékek hazai piacon, majd külföldön történő értékesítése jut mind jelentősebb szerephez. A bérmunkában folyó termelés legmunkaigényesebb fázisának részleges kiszervezése azt mutatja, hogy hosszabb távon komoly kihívás a közepes árfekvésű termékek teljes termelésének fenntartása (ma még a hazai cipőgyártók fő előnye az olcsóbb telephelyekkel szemben elsősorban az Európai Unión belüli elhelyezkedésük és termékeik jobb minősége). A termelőmunka kiszervezésével megjelenő alternatíva a közvetítői és - sikeres saját termékek esetén - az értéklánc-irányítói szerep. Nagyobb arányú, teljes termelést integráló cipőgyártás fenntartása főként az olcsóbb tömegtermelésre képes versenytársak által kevésbé fenyegetett, speciális piaci szegmensekben lehetséges.

A lábbeligyártás kiváló példa a globális és lokális kihívások által generált állandó alkalmazkodási kényszerre, amely a rendszerváltás és a globalizáció hatására jelent meg az elmúlt két évtizedben. Az iparági szereplők a túlélés és a fejlesztés érdekében stratégiáik folyamatos újragondolására kényszerülnek. Az ágazat jövőjének alakításában egyrészt a külföldi vállalatok stratégiái, másrészt a hazai cégek globális értékláncokba történő bekapcsolódásának mikéntjei, minőségi előrelépésük játszhat meghatározó szerepet.

\section{Irodalom}

Antalóczy K., Sass M. (1998): A bérmunka szerepe a világgazdaságban és Magyarországon. Közgazdasági Szemle, 7-8., 747-770.

APICCAPS (2012): World footwear yearbook 2012. Portuguese Footwear, Components and Leather Goods Manufacturers' Association, Porto. http://www.worldfootwear.com/docs/2012WorldFootwearYearbook.pdf (Letöltés: 2013. május 12.)

Barta Gy., Czirfusz M., Kukely Gy. (2008): Újraiparosodás a nagyvilágban és Magyarországon. Tér és Társadalom, 4., 1-20.

Bertram, H. (2005): Das Wandern der Schuhindustrie innerhalb Europas. Geographische Rundschau, 12., $46-53$.

Cseh J., Farkas J.-né, Geiger T., Várszegi Á. (2002): Könnyűipari ágazatok az Európai Unióban és Magyarországon: textil-, ruházati, bőr- és cipőipar. Magyar Kereskedelmi és Iparkamara, Budapest

Cséfalvay Z. (2004): Globalizáció 2.0. Nemzeti Tankönyvkiadó, Budapest

Csingár E. (2013): Felköthetjük a cipőt! Hol tart ma a nemzetközi cipőpiac? OGH Hírügynökség. http://www.esemenymenedzser.hu/hirek-elemzesek/6836-felkthetjk-a-cipt-hol-tart-ma-anemzetkzi-cippiac.html (Letöltés: 2013. május 12.)

Dicken, P. (2011): Global shift. Mapping the changing contours of the world economy. Sage, Los Angeles, London, New Delhi, Singapore, Washington D.C. 
Gereffi, G., Humphrey, J., Sturgeon, T. (2005): The governance of global value chains. Review of International Political Economy, 1., 78-104.

Humphrey, J., Schmitz, H. (2002): How does insertion in global value chains affect upgrading in industrial clusters? Regional Studies, 9., 1017-1027.

IBISWorld Industry Report (2010): Global footwear manufacturing. IBISWorld Inc. http://www.juststyle.com/store/samples/2010_IBISWorld\%20Global\%20Style\%20Sample\%20Industry\%20Report.pdf (Letöltés: 2013. május 12.)

Kaplinsky, R. (2004): Spreading the gains from globalization. What can be learned from value-chain analysis? Problems of Economic Transition, 2., 74-115.

Kiss É. (2010): Területi szerkezetváltás a magyar iparban 1989 után. Dialóg Campus Kiadó, Budapest, Pécs

Kulke, E. (2007): The commodity chain approach in economic geography. Die Erde, 2., 117-126.

Laki M. (2005): A magyar cipöpiac átalakulása 1989 után, avagy a gyenge pozitív visszacsatolás esete. http://textil.stfi.de/download/sites/download_script.asp?filename=648_91.doc(Letöltés: 2013. május 12.)

Magyarország Nemzeti Atlasza. Kartográfiai Vállalat, Budapest, 1989.

Molnár E. (2013): A magyar-román határ menti periféria gazdasági perspektívái egy ipari esettanulmány tükrében. In: Szilágyi F., Zakota Z. (szerk.): Partium társadalom-és térszerkezet. Dokumentum Kiadó, Nagyvárad, 236-248.

Navas-Alemán, L. (2011): The impact of operating in multiple value chains for upgrading: The case of the Brazilian furniture and footwear industries. World Development, 8., 1386-1397.

Schamp, E. W. (2008): Globale Wertschöpfungsketten. Umbau von Nord-Süd-Beziehungen in der Weltwirtschaft. Geographische Rundschau, 9., 4-11.

Schmitz, H. (2006): Learning and earning in global garment and footwear chains. The European Journal of Development Research, 4., 546-571.

Scott, A. J. (2006): The changing global geography of low-technology, labour-intensive industry: clothing, footwear and furniture. World Development, 9., 1517-1536.

Smahó M. (2012): A tudástranszferek rendszerei és a járműipar. In: Rechnitzer J., Smahó M. (szerk.): Jármüipar és regionális versenyképesség. Széchenyi University Press, Győr, 109-142.

Szalavetz A. (2012): A „feljebb lépési“ teljesítmény mérése a globális értékláncokon belül. Külgazdaság, 3-4., 66-86.

KSH Cég-Kód-Tár 1998/1.

KSH Cég-Kód-Tár 2010/4.

KSH Magyar statisztikai évkönyvek és a Tájékoztatási adatbázis iparági adatai. 


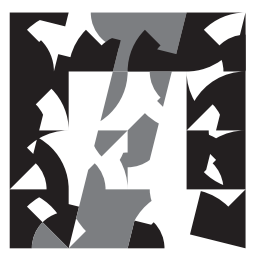

TÉR ÉS TÁRSADALOM | SPACE AND SOCIETY 